\title{
Retraction: Vitamin C and asthma in children: modification of the effect by age, exposure to dampness and the severity of asthma
}

\author{
Harri Hemilä ${ }^{1 *}$, Mohammed Al-Biltagi ${ }^{2}$ and Ahmed Abdul Baset $^{2}$
}

We reported that the effect of vitamin $\mathrm{C}$ on asthma in Egyptian children was modified by age, exposure to dampness and the severity of asthma [1]. After our paper was published, we found out severe problems in the data set. There were 60 children in the study. The ages were by accident duplicated between the upper and lower halves of the database. Thus, the ages for the first 30 children in the data set were identical and in the same order with the ages for the second set of 30 children. Similar duplication was also found for C-ACT and FEV1 measurements after vitamin $C$ supplementation and for exposure to dampness. This duplication thus directly invalidates the second part of the data set, and thus the reported outcome. We have not been able to sort out the reason for this duplication. The files with the original data are not available any more, making it impossible to reconstruct a valid data set for reanalysis. Therefore we have to retract our paper. The authors deeply regret the inconvenience this has caused to the journal and the scientific community.

\section{Author details}

${ }^{1}$ Department of Public Health, University of Helsinki, Helsinki, Finland.

${ }^{2}$ Department of Paediatrics, Faculty of Medicine, Tanta University, Tanta

Gharbia Governorate, Egypt.

Received: 12 March 2012 Accepted: 16 March 2012

Published: 16 March 2012

\section{Reference}

1. Hemilä H, Al-Biltagi M, Basset AA: Vitamin C and asthma in children: modification of the effect by age, exposure to dampness and the severity of asthma. Clinical and Translational Allergy 2011, 1:9.

doi:10.1186/2045-7022-2-6

Cite this article as: Hemilä et al:: Retraction: Vitamin C and asthma in children: modification of the effect by age, exposure to dampness and the severity of asthma. Clinical and Translational Allergy 2012 2:6.

\section{* Correspondence: harri.hemila@helsinki.fi}

${ }^{1}$ Department of Public Health, University of Helsinki, Helsinki, Finland

Full list of author information is available at the end of the article

Submit your next manuscript to BioMed Central and take full advantage of:

- Convenient online submission

- Thorough peer review

- No space constraints or color figure charges

- Immediate publication on acceptance

- Inclusion in PubMed, CAS, Scopus and Google Scholar

- Research which is freely available for redistribution
() Biomed Central 